\title{
EXPERIENCIES IN OBTAINING POLYMERIC COMPOSITES REINFORCED WITH NATURAL FIBER FROM ECUADOR
}

\author{
Jorge I. Fajardo ${ }^{1, *}$, Luis E. Valarezo ${ }^{2}$, Luis M. López ${ }^{3}$ y Andrés P. Sarmiento ${ }^{4}$
}

\section{Abstract}

This review presents the research reports related to the development of new polymeric composites reinforced with natural fibers and agro-industrial wastes from Ecuador. Vegetable fibers with potential are analyzed to be used as reinforcement in polymeric composites. It summarizes the relevant results from the different investigations analyzed. Aspects such as the type of matrix, the fiber morphology, surface treatment and mechanical properties are presented.

Keywords: Polymeric composites, natural fibers, surface modification, interface, cellulose.

\section{Resumen}

Esta revisión presenta los reportes de las investigaciones relacionadas con el desarrollo de nuevos materiales compuestos poliméricos reforzados con fibras naturales y desechos agroindustriales provenientes del Ecuador. Se analizan las fibras vegetales con potencial para ser empleadas como reforzante en compuestos poliméricos. Se sintetizan los resultados relevantes de las diferentes investigaciones analizadas. Aspectos como el tipo de matriz, la morfología de las fibras, los tratamientos superficiales y las propiedades mecánicas son presentados.

Palabras clave: Compuestos poliméricos, fibras naturales, modificación superficial, interfase, celulosa.

\footnotetext{
${ }_{1, *}$ Ingeniero mecánico, estudiante de Doctorado en Ingenierías - Materiales, Universidad Pontificia Bolivariana sede Medellín, Colombia. Docente de la Carrera de Ingeniería Mecánica de la Universidad Politécnica Salesiana, Investigador del Grupo de Materiales (GIMA - CIDII). Autor para correspondencia : jfajardo@ups.edu.ec

${ }^{2}$ Colaborador del Grupo de Investigación en Materiales (GIMA - CIDII), Estudiante de la Carrera de Ingeniería Mecánica de la Universidad Politécnica Salesiana.

${ }^{3}$ Ingeniero mecánico, egresado de la Maestría en Sistemas Integrados en Seguridad, Calidad y Medio Ambiente, Universidad Politécnica Salesiana. Docente de la Carrera de Ingeniería Mecánica de la Universidad Politécnica Salesiana, Investigador del Grupo de Materiales (GIMA - CIDII). Autor para correspondencia llopez@ups.edu.ec

${ }^{4}$ Colaborador del Grupo de Investigación en Materiales (GIMA - CIDII), estudiante de la Carrera de Ingeniería Mecánica de la Universidad Politécnica Salesiana.
}

Recibido: 27-05-2013, Aprobado tras revisión: 11-06-2013.

Forma sugerida de citación: Fajardo, J.; Valarezo, L.; López L. y Sarmiento, A. (2013). "Experiencies in obtaining polymeric composites reinforced with natural fiber from Ecuador". INGENIUS. N. ${ }^{\circ}$, (Enero-Junio). pp. 28-35. ISSN: 1390-650X. 


\section{Introducction}

The development of new materials has taken great care in the use of renewable raw materials [1]. European and U.S. industry automotive manufacturing has created regulations requiring the gradual increase of components made from polymeric composites reinforced with natural fibers [2].

Countries like Ecuador whose economic balance is negative have the opportunity to take advantage of the biodiversity they possess of natural reinforcing to generate high mechanical properties and become exporters of value-added benefit of their economies [3].

Composites with polymeric matrix provide a simple way of processing, high productivity, moderate mechanical properties, ability for recycling, a low density, and other benefits [4]. The use of natural reinforcing relies on its low density, thermal and acoustic insulation, good mechanical strength, low cost, high availability and high specific properties [4] [5].

The most important benefit of these composites is ecological; they are friendly to the environment in its composition and in its production [6]. These natural reinforcements are being used as substitute for the glass fibers and asbestos [7].

In Ecuador, in the last six years, research and experimental developments of polymeric composites reinforced with natural fibers and agro-industrial wastes have been increased [1] [8] [9] [10] [11] [12] [13] [14] [15] [16].

In this paper we will review the results of research accomplished in Ecuador around polymeric composites reinforced with natural fibers and will outline the opportunities for the study for future research.

\section{Nomenclature}

The nomenclature for the different properties analyzed and the matrix used are presented in the Table 1 .

Table 1. Nomenclature used for different fibers, matrix and treatments.

\begin{tabular}{ll}
\hline Abbreviation & Description \\
\hline v/v & Fiber volumetric fraction \\
MTS & Maximum tensile strain \\
MFS & Maximum flexural strain \\
EM & Tensile elastic modulus \\
FEM & Flexural elastic modulus \\
I & Resistence to impact \\
TP & Themoplastic \\
TE & Thermostable \\
BD & Biodegradable \\
CT & Chemical treatment \\
\hline
\end{tabular}

\section{Potential natural fibers for polymeric composites}

Natural fibers have acquired great importance in recent years for reinforcing polymeric composites with the aim of reducing the dependence of synthetic [17] fibers and glass fibers [18].

The main attraction of these fibers is that they are renewable and most of them are derived from agroindustrial waste in which the cellulose content is important [1] [4] [8] [9]. Other advantages of natural fibers as reinforcement in composites, are their biodegradation properties, low density, non-abrasiveness, high specific modulus and strength, ability to adapt to mass production processes and they do not release toxic agents when they are processed [19].

Lignocellulosic vegetable fibers are obtained from different parts of the plant, the most resistant are those present in the bark, stems and stover [20].

Fiber extraction methods are diverse and involve mechanical, physical and chemical methods combined, currently are intensively studied in order to avoid the loss of mechanical properties and that can be processed in a quick and economical way [2] [17] [18] [21].

Ecuador, there is a potential field of natural fiber production because of its biological wealth that has positioned it within the richest countries of biodiversity in the world. It is home to $10 \%$ of all plants species on the planet [22] and until now it has exploited just $0.1 \%$ in the production of fibers [20]. Therefore it provides high availability and variety of plant fibers for use as reinforcing material in composites.

Currently, Ecuador, takes advantage of handicrafts, about 25 species of plants for the production of fibers, among the most common are: hemp, reed, abaca, kapok, palms, straw shawl, cotton, silk, bamboo, achiote and guadua [23]. These account for $2.5 \%$ of Ecuadorian production [24]. Other elements rich in fiber that have not been sufficiently exploited are agro waste from banana, sugar cane bagasse, rice husk and coconut shell [1] [8] [25] . These waste products have the advantage of being raw materials for their high availability and very low cost [26].

The main difference between the various plant fibers is related to the amount, distribution and orientation of cellulose microfibial [20].

Cellulose is the major constituent of plant elements and gives resistance to plant cell walls [26]. Therefore, it is essential the selection of natural fibers that contain a high percentage of cellulose in their chemical composition, with values between $40 \%$ and $95 \%$.

Table 2 shows the chemical composition of different plant fibers high availability in Ecuador. The high 
Table 2. Chemical Composition of fibers and fiber bundles available in Ecuador.

\begin{tabular}{|c|c|c|c|c|c|c|c|}
\hline Fiber & Cellulose (\%) & Hemicellulose (\%) & Lignin (\%) & Pectin (\%) & Waxes (\%) & Humidity (\%) & Ref. \\
\hline Pineapple & $80-81$ & $16-19$ & 12 & $2-2.5$ & - & - & {$[27]$} \\
\hline Banana & $60-65$ & $6-19$ & $5-10$ & $3-5$ & - & $10-12$ & {$[27][28]$} \\
\hline Sisal & $66-78$ & $10-14$ & $10-14$ & 10 & 2 & $10-22$ & {$[28]$} \\
\hline Abacá & $56-63$ & 21 & $12-13$ & $0.8-1$ & - & $5-10$ & {$[27][28]$} \\
\hline Henequén & $60-78$ & $4-28$ & $8-13$ & $3-4$ & - & - & {$[27]$} \\
\hline Coconut & $32-43$ & $0.15-0.25$ & $40-45$ & $3-4$ & - & 8 & {$[28]$} \\
\hline Kenaf & $45-57$ & 21.5 & $8-13$ & $03-5$ & - & - & {$[28]$} \\
\hline Jute & $61-71.5$ & $13.6-20.4$ & $12-13$ & 0.2 & 0.5 & $12.5-13.7$ & {$[28]$} \\
\hline Wheat & $29-51$ & - & $16-21$ & $26-32$ & - & - & {$[29]$} \\
\hline Oats & $31-48$ & - & $16-19$ & $27-38$ & - & - & {$[29]$} \\
\hline Barley & $31-45$ & - & $14-15$ & $24-29$ & - & - & {$[29]$} \\
\hline Rice & $28-48$ & - & $12-16$ & $23-28$ & - & - & {$[29]$} \\
\hline Bagasse & $32-48$ & 30 & $18-26$ & $27-32$ & - & - & [27] [29] \\
\hline Bamboo & $26-43$ & - & $21-31$ & $15-26$ & - & - & [29] \\
\hline
\end{tabular}

content of cellulose fibers makes them have a potential use as reinforcements.

The most important quality criteria for application as a reinforcement of composites is the tensile of strength of the fibers [20]. Table summarizes the physical and mechanical properties of various natural fibers available in Ecuador.

It was not feasible to obtain a complete listing of all the properties of the fibers because each author makes particular tests of the fibers under different conditions and different test methods. It can be seen the wide diversity in resistances and modulus that these vegetables fibers present according to the age of the plant, the height of the crop, the extraction process and the part of plant used.

\section{Polymeric matrix used for composites with natural fibers}

The matrix is the composite body, gives it its shape, surface resistance, environmental stability, charge transfer and durability. Given these requirements, polymeric matrices have been widely accepted for forming composites and are able to provide advantages such as electrical insulation, low density, corrosion resistance, low production costs, wide variety of shapes, high rigidity, biodegradation and others [34].

Currently, there are various polymeric matrixes available for composite materials based on natural fibers, selection depends primarily on the temperature of use of the compound and desired processing facilities [4].

Thermoplastic matrices have linear or branched molecular chains, possess strong intermolecular bonds and weak bonds between chains. They have low melting temperatures which make them easily formable. They are usually recyclable.
The thermostable matrix present covalent links and crosslinked chains. These do not melt when heat is applied; they decompose. They can be used at moderate temperatures. Most thermostable matrixes come as liquid formulations, which facilitates the dispersion of the fibers. These are not recyclable.

Elastomeric matrix have chains with few molecular crosslinking, therefore they are very elastic. Elastomers, which are used more as matrixes of composites are natural rubbers.

Biodegradable matrixes are new and have the advantage of being biodegradable. These can be used in massive consumption products but with a short life cycle. The composites formed with these matrix and reinforced with natural fiber composites are called green composites [34].

Experiences in Ecuador for the development of composite materials reinforced with natural fibers include thermoplastic matrix [8] [9] [10] [11] [13], thermostable [14] [16] [25] and biodegradable [12]. Predominates the use of thermoplastic matrix for easiness of processing and low energy consumption. Table 4 shows the polymeric matrix used in the Ecuadorian research and the status in which they were processed.

Table 4. Matrix used for elaboration of reinforced composites with natural fibers in Ecuador.

\begin{tabular}{llll}
\hline Matrix & Type & Status & Ref. \\
\hline Unsaturated resin & TE & Diluted & {$[13][14][16]$} \\
Urea-formaldehyde & TE & Diluted & {$[25]$} \\
resin & & & \\
Polylactic acid & BD & Pellet & {$[12]$} \\
$\begin{array}{l}\text { Polyethylene } \\
\text { High TP }\end{array}$ & Sheet & {$[11]$} \\
$\begin{array}{l}\text { polyethylene } \\
\text { Polypropylene }\end{array}$ & TP & Pellet & {$[8]$} \\
\hline
\end{tabular}


Table 3. Mechanical properties: fibers and fibers bundles available in Ecuador.

\begin{tabular}{lllllllll}
\hline Fiber & $\begin{array}{l}\text { Density } \\
\left(\mathrm{g} / \mathrm{cm}^{3}\right)\end{array}$ & $\begin{array}{l}\text { Diameter } \\
(\mu \mathrm{m})\end{array}$ & $\begin{array}{l}\text { Length } \\
(\mathrm{mm})\end{array}$ & $\begin{array}{l}\text { Elongation } \\
(\%)\end{array}$ & $\begin{array}{l}\text { Tensile } \\
\text { Resistance } \\
(\mathrm{MPa})\end{array}$ & $\begin{array}{l}\text { Modulus } \\
(\mathrm{GPa})\end{array}$ & $\begin{array}{l}\text { Specific } \\
\text { modulus }\end{array}$ & $\begin{array}{l}\text { Ref. } \\
\text { Kenaf core }\end{array}$ \\
& 0.31 & $18-37$ & $0.4-1.1$ & - & - & - & - & {$[30]$} \\
Kenaf external & 1.2 & $12-36$ & $1.4-11$ & $2.7-6.9$ & $295-930$ & - & - & {$[30]$} \\
Jute & 1.46 & $5-25$ & $0.8-6$ & $1.5-3.1$ & $187-773$ & $10-30$ & $7-21$ & {$[30]$} \\
Bagasse & $0.55-1.25$ & $32-43$ & $0.8-2.8$ & 0.9 & $20-290$ & $2.7-17$ & $5-14$ & {$[27][30]$} \\
Bamboo & $0.6-0.8$ & $7-27$ & $1.5-4.4$ & $2.88-3.52$ & $187-1152$ & $8-150$ & - & {$[21][31]$} \\
Coconut & $1.15-1.46$ & $0.3-3$ & $0.3-3$ & $1.5-25$ & $131-220$ & $4-6$ & $2.58-4.10$ & {$[28][30]$} \\
Pineapple & $1.5-1.56$ & $8-41$ & $3-8$ & $1-3$ & $170-1627$ & 62.182 & $4-53$ & {$[27][30]$} \\
Banana & $1.3-1.35$ & $50-280$ & - & $3-10$ & $529-914$ & $7-32$ & $5-24$ & {$[27]$} \\
Sisal & $1.3-1.5$ & $7-200$ & $0.8-8$ & $1.9-3$ & $507-855$ & $9.4-28$ & $7-19$ & {$[27][28][30]$} \\
Abaca & $1.3-1.5$ & $17-21$ & - & 2.7 & $400-1289$ & $45-72$ & $35-50$ & {$[27][32]$} \\
Henequén & 1.4 & $8-33$ & - & $3-4.7$ & $430-580$ & $10-16$ & $7-11$ & {$[30]$} \\
Glass E & 2.56 & $8-14$ & - & $1.8-3.2$ & $1400-2500$ & 76 & 30 & {$[33]$} \\
\hline
\end{tabular}

\section{Processing of polymeric composites reinforced with natural fibers}

The experimental works done in the country, employ different combinations of natural fibers and polymeric matrix. The morphology of reinforcement includes short fiber, long fibers, continuous fibers and fabrics.

There is no report of works with nano fibers. Table 5 shows the fibers used in the Ecuadorian research and the fiber length used. No technical data are reported about the relationship between the fiber aspect, the lineal density of the thread or the surface density of the tissue in most jobs.

The procedures for obtaining the compound are: manual stratification [13] [14] [16] [35], compression molding, [10] [11] [12] [13] [14] [15] [16] [25] [35], extrusion molding [9] [8], thermoforming [10] [11] [12] [15] and injection [9].

The processing problems these material showed are associated with difficulties in interparticle adhesion [9], coalescence in the extruder screw, viscosity increment of polymeric matrix [8], low adhesion between fiber and matrix [14] [16], pore formation by moisture in the fibers, increased manufacturing time [15], manufacturing problems with high fiber ratios $\mathrm{v} / \mathrm{v}$, lack of agglomeration of composites with short fiber [10], wrong distribution of fibers in the thermoplastic matrix and the need of thicker product [11].

Most of the problems occur because of the low compatibility between natural fibers with polymeric matrix because these are hydrophobic, while the natural fibers are hydrophilic. This creates poor adhesion and thus poor properties at the interface which causes low resistance in polymer composites reinforced with natural fibers [1].
Table 5. Morphology of fibers used for elaboration of composites with natural fibers in Ecuador.

\begin{tabular}{lll}
\hline Natural fiber & Fiber length & Ref. \\
\hline & Short & {$[13][14]$} \\
Abaca & Long & {$[12][15]$} \\
& Continuous & {$[10][11]$} \\
Cabuya & Continuous & {$[16]$} \\
Coconut & Short & {$[9][35]$} \\
Rice husks & Short & {$[9][25][8]$} \\
Bagasse & Short & {$[9][25][8]$} \\
Banana & Long & {$[1]$} \\
Palm rachis & Short & {$[9]$} \\
\hline
\end{tabular}

\section{Surface treatments for natural fibers}

To improve the compatibility of natural fibers with polymer matrix, mercerization with caustic treatments have been performed. This treatment reduces the presence of hemicellulose, lignin and pectin [20]. Mercerizing causes loss of mass in the fiber and reduction of mechanical properties, as reported in the results of analyzed investigations in which it achieved greater compatibility between fiber and matrix, but significantly decreased tensile strength of the fibers [10].

Otherwise to increase the surface energy of the fiber and improve the wettability and coupling with the polymeric matrix, maleic anhydride treatments have been researched [1]. Investigations realize greater benefits in fibers, which have previously been mercerized.

The chemical treatment can be performed to the fiber and to the polymeric matrix as well. It is preferred to modify the matrix to prevent property losses in the fibers.

It is reported worldwide that a wide variety of surface treatment are used to improve compatibility 
between natural fibers and polymer matrices. It is recommended to use coupling agents such as silane, grafts of maleic anhydride and acrylic acid in polyethylene and polypropylene, Epolene C-18, Silane A-172 and A-174, zirconates, titanates, treatment with sodium hydroxide, with isocyanate and peroxides [4].

\section{Interface}

The interface must ensure the transfer of external loads into the matrix and the fiber. If these objectives are not achieved, there will be a load and not reinforcement.

To improve the interface characteristics it is necessary to increase the surface area of the fibers by mechanical processes to give a surface roughness [15]. Otherwise it should improve the wettability of the pair fiber-matrix. It can be achieved by increasing the surface energy of the fiber by heat treatment or by plasma discharge, corona treatment and mercerization [16]. Another alternative is to reduce the surface energy of the matrix with chemical treatments of acetylation, zirconates and stearates which are required to reduce the surface energy of the aggregate [15].

\section{Mechanical properties of polymeric composites reinforced with natural fibers}

The mechanical properties studied in the polymeric composites reinforced with natural fibers showed wide diversity. No all tests are available for each compound developed. The diversity of the results depends on factors such as the volumetric fraction of fibers, the morphology of the composite, the aspect ratio of the fibers, the quality of the interface, the load transfer mechanism and the surface treatment applied. The best results have been analyzed by type of matrix used. Table 6 summarizes the best results obtained in the different configurations of composites.

\section{A - Thermostable matrix}

In applications of reinforced polyester resin with abaca fiber by manual stratification have succeeded in increasing the $270 \%$ tensile stress, $124 \%$ elastic modulus, $82 \%$ of the flexural modulus and $428 \%$ average of impact effort with longitudinally oriented fibers[13]. The mechanical properties of polyester resin composites reinforced with cabuya fibers manually stratified have increased $159 \%$ the tensile strength with longitudinal reinforcement [16].

Studies made in hybrid materials of polyester resin reinforced with glass fibers and by abaca manual layering reported increased tensile strength at $270 \%, 150 \%$ in the elastic modulus, $113 \%$ at the maximum bending stress, $122 \%$ in the flexural modulus and $603 \%$ in the impact resistance [14].

Hybrid composite polyester resin reinforced with glass fibers and coconut by stratification increased $236 \%$ in the elastic modulus, $40 \%$ in maximum tensile stress, $103 \%$ in the flexural modulus, $50 \%$ in the resistance to bending and $361 \%$ in the impact energy [35].

\section{B - Thermoplastic matrix}

Polypropylene hybrid composites reinforced with glass fibers and abaca by compression molding reported an increase of $500 \%$ in tensile strength and $900 \%$ in the elastic modulus [15].

Reinforced polypropylene with abaca fibers by compression molding report an increase of $337 \%$ in the elastic modulus for continuous unidirectional fiber and $176 \%$ increase in tensile stress to maximum continuous fiber [10]. Polyethylene composites reinforced with abaca fiber by compression molding show an increase of $500 \%$ in modulus unidirectional continuous fiber [11]. High density polyethylene with rice husk and bagasse reported $10 \%$ increase in impact properties.

\section{C - Biodegradable Matrix}

Polylactic acid composites reinforced with abaca fiber reported a 165\% increase in tensile strength, 130\% modulus in tensile strength, $50 \%$ in the maximum flexural strength, $100 \%$ in the modulus of elasticity in bending, impact resistance of $200 \%$ in unnotched specimen and $1000 \%$ in notched specimen [12].

\section{Future challenges}

Researches done in Ecuador have shown the structural capacity that polymeric composites reinforced with natural fibers have. However much work remains to be done to improve the performance and turn them into raw material with high added value.

Aspects such as the chemical, physical and mechanical characterization must be approached and improved. It is necessary to standardize the tests for natural fibers and reinforced composites with these fibers. It requires find the optimal alternative surface treatment to ensure the coupling to the matrix without reduce the strength of the fibers. At an advanced stage is necessary to work in order to establish mathematical models of the mechanical behavior of the composites to ensure the performance of the products made from these materials. 
Table 6. Better mechanical properties obtained in polymeric composites materials reinforced with natural fibers in Ecuador.

\begin{tabular}{|c|c|c|c|c|c|c|c|c|c|c|c|c|}
\hline \multirow[b]{2}{*}{ Composite } & \multicolumn{7}{|c|}{ Better results in their configurations } & \multicolumn{3}{|c|}{ ASTM test } & \multirow[t]{2}{*}{ CT } & \multirow[t]{2}{*}{ Ref. } \\
\hline & $\mathrm{v} / \mathrm{v}$ & $\begin{array}{l}\text { MTS } \\
(\mathrm{MPa})\end{array}$ & $\begin{array}{l}\text { MFS } \\
(\mathrm{MPa})\end{array}$ & $\begin{array}{c}\text { EM } \\
(\mathrm{MPa})\end{array}$ & $\begin{array}{l}\text { FEM } \\
(\mathrm{MPa})\end{array}$ & $\begin{array}{c}\mathbf{I} \\
(\mathrm{J})\end{array}$ & $\underset{(\mathrm{J} / \mathrm{m})}{\mathbf{I}}$ & Tensile & Bending & Impact & & \\
\hline Polyester - abaca & 0.30 & 140 & 110 & 4000 & 12500 & - & - & D3038- 08 & D7264M - 07 & D5628 - 10 & No & {$[13]$} \\
\hline Polyester - cabuya & $0.30-0.34$ & 263 & 130 & 6508 & 4434 & - & - & D3038 - 08 & D7264M - 07 & D5628 - 10 & No & {$[16]$} \\
\hline Polyester - glass fiber - abaca & 0.2 & 89 & 125 & 4271 & 122 & 0.492 & - & D3038 - 08 & D7264M - 07 & D5628 - 10 & No & {$[14]$} \\
\hline Polyester - glass fiber - coconut & 0.15 & 54 & 110 & 4987 & 4484 & - & - & D3038 - 08 & D7264M - 07 & D5628 - 10 & No & {$[35]$} \\
\hline $\begin{array}{l}\text { Polypropylene - glass fiber - } \\
\text { abaca }\end{array}$ & 0.25 & 140 & 75 & 11096 & 4415 & 9 & - & D3038 - 08 & D7264M - 07 & D5628 - 10 & No & {$[15]$} \\
\hline PLA - abaca & 0.2 & 132 & 104.4 & 9.223 & 5.57 & - & 711 & D3038 - 08 & D7264M - 07 & D5628 - 10 & No & {$[12]$} \\
\hline Polypropylene - abaca & 0.35 & 142 & 88 & 1966 & 3266 & - & - & D3038 - 08 & D7264M - 07 & D5628 - 10 & Yes & {$[10]$} \\
\hline Polyethylene - abaca & 0.35 & 102 & 38 & 1667 & 507 & - & - & D-638 & - & - & No & {$[11]$} \\
\hline HDPE - Rice husks and bagasse & 0.3 & - & - & - & - & - & 123 & $D-638$ & - & $\mathrm{D}-256$ & No & {$[8]$} \\
\hline $\begin{array}{l}\text { Polypropylene - agro-industrial } \\
\text { wastes }\end{array}$ & 0.3 & 20 & 29 & - & - & - & 23 & D - 638 & D - 790 & D - 256 & Yes & {$[9]$} \\
\hline $\begin{array}{l}\text { Urea - formaldehyde - sugar- } \\
\text { cane bagasse and rice husks }\end{array}$ & 0.9 & 103 & 1.056 & - & - & - & - & D - 1037 & D - 1037 & D - 1037 & No & {$[25]$} \\
\hline
\end{tabular}

\section{References}

[1] N. Manrique Flores and O. González, "Efectos del tratamiento químico en las propiedades físicas y mecánicas de las fibras naturales como sustitutas de la fibra de vidrio en composites," 2011.

[2] J. Holbery and D. Houston, "Natural-fiberreinforced polymer composites in automotive applications," JOM, vol. 58, no. 11, pp. 80-86, 2006.

[3] J. Fajardo, M. Amaya, F. Novillo, and G. Romero, "Diagnóstico del desarollo tecnológico de la ciencia de materiales en las PYMES de la ciudad de Cuenca," Ingenius: Revista de Ciencia y Tecnología, vol. 2, no. 6, pp. 37-50, 2011.

[4] D. N. Saheb and J. P. Jog, "Natural fiber polymer composites: A review," Advances in Polymer Technology, vol. 18, no. 4, pp. 351-363, 1999.

[5] K. M. M. Rao and K. M. Rao, "Extraction and tensile properties of natural fibers: Vakka, date and bamboo," Composite Structures, vol. 77, no. 3, pp. $288-295,2007$.

[6] A. Mohanty, M. Misra, and G. Hinrichsen, "Biofibres, biodegradable polymers and biocomposites: An overview," Macromolecular Materials and Engineering, vol. 276, no. 1, pp. 1-24, 2000.

[7] A. F. Blanxart, NTP 306: Las fibras alternativas al amianto: consideraciones generales. [Online]. Available: http://www.saludlaboral.ugtcyl. es/archivos/amianto/

[8] J. M. Cevallos García, "Estudio comparativo de las propiedades mecánicas y reológicas de compuestos de polietileno de alta densidad con cascarilla de arroz y bagazo de caña," Proyecto de Graduación, Escuela Superior Politécnica del
Litoral, Guayaquil, Ecuador, 2008. [Online]. Available: http://www.dspace.espol.edu.ec/bitstream/ 123456789/10672/1/D-39728.pdf

[9] C. Tapia, C. Paredes, and C. Correa, "Comparación de las propiedades de compuestos en base de polipropileno en mezcla con diversos residuos agroindustriales del ecuador," Proyecto de Graduación, Escuela Superior Politécnica del Litoral, Guayaquil, Ecuador, 2009. [Online]. Available: http://www.dspace.espol.edu.ec/ handle/123456789/4750

[10] J. C. Páez Moscoso, "Obtención de compuestos de polidropileno reforzado con fibras de abacá mediante moldeo por compresión," Proyecto de Graduación, Escuela Politécnica Nacional, Quito, Ecuador, 2007. [Online]. Available: http://bibdigital.epn.edu.ec/handle/15000/352

[11] A. P. Salas Balseca, "Obtención de compuestos de polietileno reforzado con fibras de abacá mediante moldeo por compresión," Proyecto de Graduación, Escuela Politécnica Nacional, Quito, Ecuador, 2009. [Online]. Available: http://bibdigital.epn.edu.ec/handle/15000/1134

[12] S. D. Ponce Cahuasqui, "Obtención de materiales compuestos de matriz polimérica biodegradable reforzada con fibra natural," Proyecto de Graduación, Escuela Politécnica Nacional, Quito, Ecuador, 2011.

[13] P. Pontón and V. H. Guerrero, "Obtención de materiales compuestos de matriz poliéster reforzados con fibra de abacá mediante estratificación manual," Revista Tecnológica ESPOL, vol. 23, no. 3, 2011. [Online]. Available: http://www.rte.espol. edu.ec/index.php/tecnologica/article/view/62

[14] H. G. Villacís Salazar, "Obtención de materiales compuestos híbridos de matriz 
poliéster reforzados con fibra de vidrio y abacá mediante estratificación," Proyecto de Graduación, Escuela Politécnica Nacional, Quito, Ecuador, 2011. [Online]. Available: http://bibdigital.epn.edu.ec/handle/15000/4036

[15] J. P. Cevallos Espinosa and J. G. Tenesaca Bravo, "Obtención y caracterización de materiales compuestos híbridos de matriz polipropileno reforzadas con fibras de vidrio y abacá mediante moldeo por compresión," Proyecto de Graduación, Escuela Politécnica Nacional, Quito, Ecuador, 2012.

[16] N. A. Tamayo Duque, "Obtención y caracterización de materiales compuestos de matriz poliéster reforzados con fibra de cabuya mediante estratificación," Proyecto de Graduación, Escuela Politécnica Nacional, Quito, Ecuador, 2012. [Online]. Available: http://bibdigital.epn.edu.ec/handle/15000/4714

[17] A. Cuellar and I. Muñoz, "Fibra de guadua como refuerzo de matrices poliméricas," Revista Dyna, vol. 162 , no. 77 , pp. 137-142, 2010.

[18] E. Trujillo, L. Osorio, A.-W. Van Vuure, J. Ivens, and I. Verpoest, "Characterisation of polymer composite materials based on bamboo fibers," in 14th European Conference on Composite Materials. Budapest, Hungary: Budapest University of Technology and Economics. Department of Polymer Engineering, 7-10 June 2012.

[19] M. P. Lucena, A. Suarez, and I. Zamudio, "Desarrollo de un material compuesto a base de fibras de bambú para aplicaciones aeronáuticas," Revista Latinoamericana de Metalurgia y Materiales, pp. 1107-1114, 2009.

[20] FAO, "Fibras naturales: Tejidos antiguos, geotextiles modernos," Organización de las Naciones Unidas para la Alimentación y la Agricultura, Tech. Rep., 2012. [Online]. Available: http://www.naturalfibres2009.org/es/fibras/

[21] F. Ramirez, A. Maldonado, J. Correal, and M. Estrada, "Bamboo-guadua angustifolia kunt fibers for green composites," in 18th International Conference on Composite Materials, Corea del Norte, 2011.

[22] INEFAN (Instituto Ecuatoriano Forestal y de áreas naturales y vida silvestre), "Informe interino a la secretaría del convenio de diversidad biológica, sobre la aplicación del artículo 6," Tech. Rep., Febrero 1998. [Online]. Available: http://www.ambiente.gob.ec/wp-content/ uploads/downloads/2012/07/
[23] "25 Fibras vegetales son el potencial del Ecuador," 2000. [Online]. Available: http://www.hoy.com.ec/noticias-ecuador/ 25-fibras-vegetales-son-el-potencial-del-ecuador. html

[24] A. P. Cerón López, "Estudio de factibilidad para implementar una empresa de exportación de fibra de abacá," Proyecto de Graduación, Escuela Politécnica Nacional, Quito, Ecuador, 2006. [Online]. Available: http://bibdigital.epn.edu.ec/handle/15000/434

[25] C. Tapia, C. Paredes, A. Simbaña, and A. Leao, "Elaboración de tableros de partícula fina a partir de residuos lignocelulósicos y resinas termoestables," 2009. [Online]. Available: http://www.dspace.espol.edu.ec/bitstream/ 123456789/4759/1/7319.pdf

[26] R. Zuluaga Gallego, "Aislamiento y caracterización de microfibrillas de celulosa de la pared celular de los haces vasculares del raquis de banano," Doctorado en Ingeniería, Universidad Pontificia Bolivariana, Medellín, Colombia, 2008.

[27] J. Biagiotti, D. Puglia, and J. M. Kenny, "A review on natural fibre-based composites-part I: structure, processing and properties of vegetable fibres," Journal of Natural Fibers, vol. 1, no. 2, pp. 37-68, 2004.

[28] A. K. Mohanty, M. Misra, L. T. Drzal, S. E. Selke, B. R. Harte, and G. Hinrichsen, Natural Fibers, Biopolymers, and Biocomposites. CRC Press, 2005.

[29] R. Kozlowski and M. Wladyka-Przybylak, Natural Fibers, Plastics and Composites. Kluwer Academic, 2004.

[30] R. Rowell, Properties and perfomance of naturalfibre composite. England: Woodhead Publishing Limited, 2008, ch. Natural fibers: types and properties, pp. 3-64.

[31] M. Lindholm and S. Palm, "Guadua chacoensis in Bolivia: - an investigation of mechanical properties of a bamboo species," Master's thesis, Linköping University, Suecia, 2007. [Online]. Available: http://liu.diva-portal.org/smash/get/diva2: 17115/FULLTEXT01.pdf

[32] J. L. Dávila, S. Galeas, V. H. Guerrero, P. Pontón, N. M. Rosas, V. Sotomayor, and C. Valdivieso, Nuevos materiales: aplicaciones estructurales e industriales. Quito, Ecuador: IMPREFEPP, 2011.

[33] D. Hull, Materiales compuestos. Editorial Reverté, S.A., 1987. 
[34] P. A. Sreekumar and S. Thomas, Properties and perfomance of natural-fibre composite. England: Woodhead Publishing Limited, 2008, ch. Matrices for natural-fibre reinforced composites, pp. $67-114$.
[35] F. R. Delgado Arcentales, "Obtención de materiales compuestos híbridos de matriz poliéster reforzados con fibras de vidrio y coco para la elaboración de tableros," Proyecto de Graduación, Escuela Politécnica Nacional, Quito, Ecuador, 2012. 